Romain Gary 
CRITICAL AUTHORS \& ISSUES

Josué Harari, Series Editor

A complete list of books in the series

is available from the publisher. 


\title{
Romain Gary
}

\section{The Man Who Sold His Shadow}

\author{
Ralph Schoolcraft
}

\section{$\overline{\text { PENN }}$}

University of Pennsylvania Press

PH I LA DEL PHIA 
Copyright $(2002$ University of Pennsylvania Press All rights reserved

Printed in the United States of America on acid-free paper

10987654321

Published by

University of Pennsylvania Press

Philadelphia, Pennsyluania 19104-4011

Library of Congress Cataloging-in-Publication Data

Schoolcraft, Ralph W.

Romain Gary: the man who sold his shadow /

Ralph Schoolcraft.

p. cm. - (Critical authors $\mathcal{E} v$ issues)

Includes bibliographical references and index.

ISBN 0-8122-3646-7 (cloth : alk. paper)

1. Gary, Romain. 2. Authors, French-20th centuryBiography. 3. Gary, Romain-Anonyms and pseudonyms. I. Title. II. Series.

PQ2613.A58 Z875 2001

$843^{\prime} .912-d c 21$

[B]

2001053011 